\title{
Gordonia paraffinivorans sp. nov., a hydrocarbon-degrading actinomycete isolated from an oil-producing well
}

\author{
Yanfen Xue, ${ }^{1}$ Xuesong Sun, ${ }^{1,2}$ Peijin Zhou, ${ }^{1}$ Rulin Liu, ${ }^{2}$ Fenglai Liang ${ }^{2}$ \\ and Yanhe $\mathrm{Ma}^{1}$ \\ ${ }^{1}$ Institute of Microbiology, Chinese Academy of Sciences, Beijing 100080, China \\ ${ }^{2}$ Department of Microbiology, College of Life Science, Nankai University, Tianjin 300071, China
}

Yanhe Ma

mayh@sun.im.ac.cn

\begin{abstract}
The taxonomic position of an actinomycete, strain $\mathrm{HD} 321^{\top}$, isolated from an oil-producing well of Daqing oilfield, was clarified using a polyphasic taxonomic approach. The strain possessed cell-wall chemotype IV, MK- $9\left(\mathrm{H}_{2}\right)$ as the predominant menaquinone, relatively long-chain mycolic acids (52-62 carbon atoms) of the Gordonia type, straight-chain saturated and monounsaturated fatty acids and tuberculostearic acid. The $\mathrm{G}+\mathrm{C}$ content of the DNA was 66 mol\%. 16S rDNA analyses as well as chemotaxonomic and physiological properties indicated that strain $\mathrm{HD}_{2} 21^{\top}$ represents a novel species within the genus Gordonia, for which the name Gordonia paraffinivorans sp. nov. is proposed; the type strain is $\mathrm{HD}_{2} 1^{\top}\left(=\mathrm{AS} 4.1730^{\top}=\mathrm{DSM} 44604^{\top}\right)$.
\end{abstract}

The genus Gordonia belongs phylogenetically to the suborder Corynebacterineae, the mycolic acid group within the order Actinomycetales (Stackebrandt et al., 1997). The species of Gordonia show considerable metabolic diversity and are capable of degrading toxic environment-contaminating compounds, as exemplified by the isolation of strains possessing hydrocarbon-oxidizing, rubber-degrading, aromatic-desulphurizing and 3-ethylpyridine-degrading pathways (Kummer et al., 1999; Linos et al., 2002; Kim et al., 1999; Gilbert et al., 1998; Rhee et al., 1998; Yoon et al., 2000). From the point of view of bioremediation, the genus Gordonia is a very important taxon. Some species have been used for decontamination of polluted soils and waters (Bell et al., 1998). The members of the genus Gordonia are widely distributed in various environments such as soil, activated sludge, biofilm and the mangrove rhizosphere (Tsukamura, 1971; Lechevalier \& Lechevalier, 1974; Bendinger et al., 1995; Takeuchi \& Hatano, 1998; Linos et al., 1999; Kummer et al., 1999). There are no reports of Gordonia species in the producing-well water of oilfields, which has low levels of nutrients, consisting mainly of straight-chain and aromatic hydrocarbons.

In the course of an investigation of the microflora in the Daqing oilfield formation, we isolated several hydrocarbondegrading strains from well-bore water samples (Nazina et al., 2000). A hydrocarbon-degrading bacterium, designated strain $\mathrm{HD}_{32} 1^{\mathrm{T}}$, appeared to represent a novel taxon

Published online ahead of print on 23 May 2003 as DOI 10.1099/ ijs.0.02605-0.

The GenBank/EMBL/DDBJ accession number for the $16 \mathrm{~S}$ rDNA sequence of strain $\mathrm{HD} 321^{\top}$ is AF432348. based on preliminary investigations of its phenotypic and phylogenetic characteristics. Here, we describe the physiological, chemotaxonomic and phylogenetic characteristics of strain HD32 $1^{\mathrm{T}}$ and propose a novel species of the genus Gordonia, Gordonia paraffinivorans sp. nov., for this strain.

Strain $\mathrm{HD} 321^{\mathrm{T}}$ was isolated from a water sample collected in late May 1996 from a producing well of Daqing oilfield, China. The water sample was inoculated into $100 \mathrm{ml}$ minimal salts medium containing $\left(\mathrm{l}^{-1}\right) 1.0 \mathrm{~g} \mathrm{NH}_{4} \mathrm{Cl}, 0.5 \mathrm{~g}$ $\mathrm{KH}_{2} \mathrm{PO}_{4}, 0.75 \mathrm{~g} \mathrm{Na}_{2} \mathrm{HPO}_{4} .12 \mathrm{H}_{2} \mathrm{O}, 0.2 \mathrm{~g} \mathrm{MgSO}_{2} .7 \mathrm{H}_{2} \mathrm{O}$, $0.02 \mathrm{~g} \mathrm{CaCl}_{2}$ and $10 \mathrm{ml}$ trace-element solution (Lee et al., 1991), supplemented with $5 \mathrm{ml}$ liquid paraffin. This medium was incubated at $37^{\circ} \mathrm{C}$ on a rotary shaker at 250 r.p.m. After the liquid paraffin was emulsified by growth of micro-organisms, a portion of the cultivation medium was diluted and plated on nutrient agar containing $\left(1^{-1}\right) 10 \mathrm{~g}$ tryptone, $3 \mathrm{~g}$ beef extract, $5 \mathrm{~g} \mathrm{NaCl}$ and $15 \mathrm{~g}$ agar. Strain HD $321^{\mathrm{T}}$ was isolated on nutrient agar and showed orangered colonies on glucose potato agar (GPA).

Cell morphology was determined by phase-contrast and electron microscopy. Mobility was determined by the hanging-drop method. The optimal conditions for growth were determined in nutrient broth with $0-14 \% \mathrm{NaCl}$, $\mathrm{pH} 5-10$ and at $4-60^{\circ} \mathrm{C}$. Carbon source utilization was tested in the medium described previously (Kämpfer et al., 1990). Controls were grown without substrate addition. The ability to grow in the presence of $0.1 \%$ oleic acid and $0.001 \%$ zinc chloride was tested as described previously (Kim et al., 1999). The methods used for biochemical tests were described previously (Smibert \& Krieg, 1981). The isomeric form of diaminopimelic acid in the cell wall was 
analysed using TLC according to the method of Komagata \& Suzuki (1987). The sugars of the cell wall were analysed as described previously (Saddler et al., 1991). Menaquinones were extracted and purified from freeze-dried cells using the method of Collins (1985) and determined by reversedphase HPLC. Fatty acid analysis was performed using standard methods and compared to the database of fatty acids in the MIDI Sherlock Microbial Identification System (Microbial ID). Mycolic acid was determined by the Deutsche Sammlung von Mikroorganismen und Zellkulturen GmbH (DSMZ, Braunschweig, Germany). Genomic DNA of the strain was prepared by the method of Marmur (1961) and the purity was checked spectrometrically. The G $+\mathrm{C}$ content of the DNA was determined by the thermal denaturation method (Marmur \& Doty,
1962). The methods used for PCR amplification of $16 \mathrm{~S}$ rRNA gene, sequencing of the PCR products and determination of the phylogenetic position were described previously (Zhang et al., 2002). The reference strains used in sequence comparison are shown in Fig. 1.

The novel strain $\mathrm{HD} 321^{\mathrm{T}}$ had morphological and biochemical properties that were consistent with its classification in the genus Gordonia (Stackebrandt et al., 1988). The strain was a Gram-positive, non-acid-fast, non-motile, rod-shaped and strictly aerobic bacterium. Cells $(0 \cdot 3-0 \cdot 5 \times 1-2 \mu \mathrm{m})$ often occurred singly or in a typical coryneform V-shape. Catalase and urease were positive. Oxidase was negative. Gelatin and cellulose were not hydrolysed. Strain $\mathrm{HD}_{32} 1^{\mathrm{T}}$ grew well at $30-37^{\circ} \mathrm{C}$ and very slowly at 20 and $45^{\circ} \mathrm{C}$. Growth

Table 1. Phenotypic characteristics that separate strain $\mathrm{HD}_{2} 21^{\top}$ from the type strains of other Gordonia species

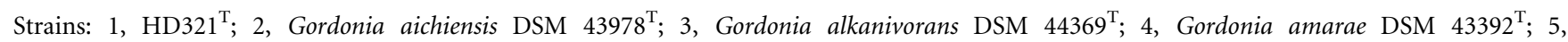
Gordonia amicalis DSM $44461^{\mathrm{T}} ; 6$, Gordonia bronchialis DSM $43247^{\mathrm{T}} ; 7$, Gordonia desulfuricans DSM 44462 ${ }^{\mathrm{T}}$; 8 , Gordonia hirsuta DSM $44140^{\mathrm{T}} ; 9$, Gordonia hydrophobica DSM 44015 ${ }^{\mathrm{T}}$; 10, Gordonia namibiensis DSM 44568 ${ }^{\mathrm{T}}$; 11, Gordonia nitida DSM 44499 ${ }^{\mathrm{T}}$; 12 , Gordonia polyisoprenivorans DSM 44302 $2^{\mathrm{T}}$; 13, Gordonia rhizosphera NBRC $16068^{\mathrm{T}}$; 14, Gordonia rubripertincta DSM 43197 ; 15, Gordonia sputi DSM $43896^{\mathrm{T}}$; 16, Gordonia terrae DSM 43249 ${ }^{\mathrm{T}}$; 17 , Gordonia westfalica DSM $44215^{\mathrm{T}}$. Data were taken from this study and from Brandão et al. (2001), Linos et al. (2002) and Yoon et al. (2000).

\begin{tabular}{|c|c|c|c|c|c|c|c|c|c|c|c|c|c|c|c|c|c|}
\hline Character & 1 & 2 & 3 & 4 & 5 & 6 & 7 & 8 & 9 & 10 & 11 & 12 & 13 & 14 & 15 & 16 & 17 \\
\hline \multicolumn{18}{|l|}{ Assimilation of: } \\
\hline D-Arabitol & - & - & - & + & - & - & - & - & - & + & - & + & - & + & + & + & + \\
\hline D-Cellobiose & - & - & - & - & - & - & - & + & - & - & - & - & + & - & - & - & - \\
\hline L-Rhamnose & - & - & - & - & + & + & - & - & - & ND & - & + & + & + & - & + & - \\
\hline Sucrose & + & - & + & + & + & + & + & - & + & - & + & + & - & + & - & + & + \\
\hline Succinate & - & - & + & - & + & + & - & - & + & + & - & - & - & - & + & - & - \\
\hline Glycerol & + & + & + & + & + & + & + & + & + & + & + & - & $\mathrm{ND}$ & + & + & + & ND \\
\hline L-Alanine & + & + & - & - & + & + & + & - & - & - & + & + & + & + & - & - & - \\
\hline L-Leucine & + & - & + & - & + & + & + & - & + & - & - & - & - & - & - & - & - \\
\hline Xanthine & - & - & - & - & - & - & - & - & - & - & - & - & - & - & + & + & ND \\
\hline Tyrosine & - & - & - & + & - & - & - & - & + & - & - & - & - & - & - & - & ND \\
\hline Starch & - & - & + & + & + & + & + & + & - & - & - & + & + & + & + & + & ND \\
\hline Tween 80 & + & + & + & - & - & - & + & + & + & - & + & + & - & - & - & - & ND \\
\hline Uric acid & - & + & - & + & - & + & + & - & + & + & + & + & + & + & + & + & ND \\
\hline \multicolumn{18}{|l|}{ Hydrolysis of: } \\
\hline Aesculin & + & - & - & + & - & - & - & - & + & + & + & - & - & - & + & + & ND \\
\hline Allantoin & + & - & - & + & - & - & - & - & + & + & - & - & - & - & - & - & ND \\
\hline Arbutin & - & + & - & + & - & - & - & - & + & - & - & - & - & + & + & + & ND \\
\hline Urea & + & + & + & + & - & + & + & - & - & + & + & + & - & + & + & + & ND \\
\hline Nitrate reduction & - & + & + & - & - & + & + & + & + & - & - & - & - & - & + & + & ND \\
\hline
\end{tabular}

${ }_{\mathrm{B}} \mathrm{B}$, Brown; LY, light yellow; O, orange; $\mathrm{P}$, pink; PO, pastel orange; $\mathrm{R}$, red; $\mathrm{T}, \mathrm{tan} ; \mathrm{W}$, white.

ND, Not determined. 
occurred in medium containing $0 \cdot 5-7 \%(\mathrm{w} / \mathrm{v}) \mathrm{NaCl}$ and at pH 5.5-9.5. Some other biochemical properties useful for identifying and differentiating strain $\mathrm{HD} 321^{\mathrm{T}}$ and type strains of other species of the genus Gordonia are represented in Table 1 and in the description of the species.

The chemotaxonomic properties of strain $\operatorname{HD} 321^{\mathrm{T}}$ were consistent with the chemotaxonomic markers of the genus Gordonia (Chun et al., 1997; Takeuchi \& Hatano, 1998; Stackebrandt et al., 1988). The cell wall of strain HD $321^{\mathrm{T}}$ contained meso-diaminopimelic acid as the only diamino acid and arabinose and galactose as the major cell-wall sugars, indicating that the wall chemotype was type IV (Lechevalier \& Lechevalier, 1970). The predominant menaquinone was MK-9 $\left(\mathrm{H}_{2}\right)$. The fatty acid profile of strain HD $321^{\mathrm{T}}$ was composed of $\mathrm{C}_{16: 0}(25 \cdot 8 \%)$, tuberculostearic acid (10-methyl- $\left.\mathrm{C}_{18: 0}\right)(22 \cdot 4 \%), \mathrm{C}_{18: 1} \omega 9 c(20 \cdot 5 \%)$, summed feature $4\left(\mathrm{C}_{16: 1} \omega 7 c\right.$ and/or i- $\left.\mathrm{C}_{15: 0} 2-\mathrm{OH}\right)(11.5 \%), \mathrm{C}_{18: 0}$ $(9 \cdot 3 \%), \mathrm{C}_{14: 0}(2 \cdot 7 \%), \mathrm{C}_{17: 0}(2 \cdot 2 \%), \mathrm{C}_{17: 1} \omega 8 c(1 \cdot 6 \%)$ and $\mathrm{C}_{20: 0}(1 \cdot 2 \%)$. Mycolic acids ranged from 52 to 62 carbon atoms $\left(2 \cdot 8 \% \mathrm{C}_{52}, 6 \cdot 7 \% \mathrm{C}_{54}, 25 \cdot 2 \% \mathrm{C}_{56}, 2 \cdot 5 \% \mathrm{C}_{57}, 41 \%\right.$ $\mathrm{C}_{58}, 1 \% \mathrm{C}_{59}, 19 \cdot 1 \% \mathrm{C}_{60}, 1 \cdot 7 \% \mathrm{C}_{62}$ ), with $\mathrm{C}_{56}$ and $\mathrm{C}_{58}$ being the principal mycolic acids. The $\mathrm{G}+\mathrm{C}$ content of the DNA was $66.0 \mathrm{~mol} \%$. Fine qualitative and quantitative differences in fatty acid patterns and mycolic acid chain lengths could distinguish strain HD32 $1^{\mathrm{T}}$ from type strains of other species of the genus Gordonia.

The 16S rDNA of strain HD321 ${ }^{\mathrm{T}}$ was amplified by PCR and an almost-complete nucleotide sequence (1472 bp) was determined by direct sequencing. The phylogenetic tree showed that strain $\mathrm{HD} 321^{\mathrm{T}}$ was in the cluster comprising members of the genus Gordonia and formed a monophyletic clade (Fig. 1). The $16 \mathrm{~S}$ rDNA sequence similarities between strain $\mathrm{HD} 321^{\mathrm{T}}$ and the type strains of other Gordonia species with validly published names were $95 \cdot 3-97 \cdot 6 \%$. The highest level of sequence similarity $(97 \cdot 6 \%)$ was to Gordonia amicalis and Gordonia rubripertincta. These values and the results shown in the phylogenetic tree indicate that strain $\mathrm{HD} 321^{\mathrm{T}}$ represents a novel member of the genus Gordonia (Stackebrandt \& Goebel, 1994). Because of the ability of the strain to use paraffin as a carbon source, the name Gordonia paraffinivorans sp. nov. is proposed.

\section{Description of Gordonia paraffinivorans sp. nov.}

Gordonia paraffinivorans (pa.raf.fi.ni.vo'rans. N.L. n. paraffina paraffin; L. part. adj. vorans devouring; N.L. part. adj. paraffinivorans paraffin-devouring, referring to the ability to degrade paraffin).

Aerobic, Gram-positive, non-motile, short rod-shaped bacterium $(0 \cdot 3-0 \cdot 5 \times 1-2 \mu \mathrm{m})$; orange-red colonies formed on GPA. No spore formation is observed. Oxidase-negative. Catalase- and urease-positive. Sucrose, maltose, glucose, Dfructose, D-galactose, D-mannose, inulin, dextrin, L-proline, L-alanine, L-leucine, glutamate and glycerol are used as sole sources of carbon for energy and growth. Does not

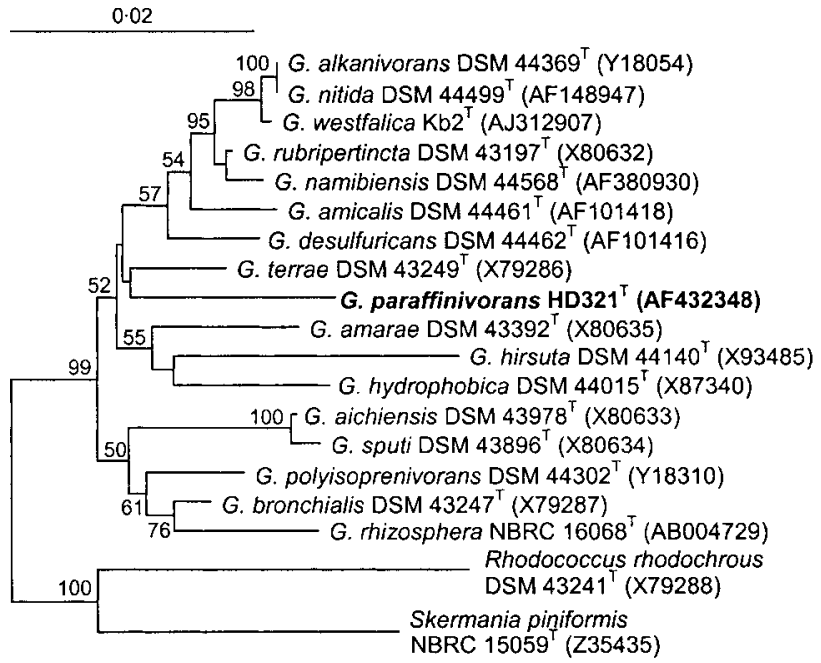

Fig. 1. Phylogenetic tree based on $16 \mathrm{~S}$ rDNA sequences showing the position of strain $\mathrm{HD} 321^{\top}$, Gordonia species and representatives of mycolic-acid-containing actinomycete taxa. Bootstrap values (expressed as percentages of 1000 replications) greater than $50 \%$ are shown at branch points. Bar, 0.02 substitutions per nucleotide position.

utilize L-arabinose, D-raffinose, L-rhamnose, D-ribose, lactose, D-cellobiose, L-sorbose, D-xylose, sorbitol, D-mannitol, D-arabitol, aesculin, L-malic acid, succinic acid, L-lysine, oxalate, citrate or tartrate. Acids are not produced from glucose, sucrose, D-mannose, D-galactose or glycerol. Hypoxanthine, xanthine, tyrosine, starch, arbutin, uric acid, gelatin, cellulose and Tween 20 are not degraded. Aesculin, allantoin and Tween 80 are hydrolysed. Growth occurs in the presence of oleic acid $(0.8 \%, \mathrm{w} / \mathrm{v})$ and zinc chloride $(0.001 \%, w / v)$. Positive for formation of $\mathrm{H}_{2} \mathrm{~S}$; negative for production of indole and methyl red test. Nitrate is not reduced to nitrite. Cell wall contains mesodiaminopimelic acid, arabinose and galactose (cell-wall chemotype IV sensu Lechevalier \& Lechevalier, 1970). The predominant menaquinone is $\mathrm{MK}-9\left(\mathrm{H}_{2}\right)$. Mycolic acids have 52-62 carbon atoms, with $\mathrm{C}_{56}$ and $\mathrm{C}_{58}$ being the principal mycolic acids. The major fatty acids are $\mathrm{C}_{16: 0}$, $\mathrm{C}_{18: 1} \omega 9 \mathrm{c}$ and 10-methyl- $\mathrm{C}_{18: 0}$ (tuberculostearic acid). The $\mathrm{G}+\mathrm{C}$ content of the DNA of the type strain is $66 \mathrm{~mol} \%$.

The type strain, strain $\mathrm{HD}_{2} 21^{\mathrm{T}}\left(=\mathrm{AS} \quad 4.1730^{\mathrm{T}}=\mathrm{DSM}\right.$ $44604^{\mathrm{T}}$ ), was isolated from a producing-well water sample from Daqing oilfield, China.

\section{Acknowledgements}

This work was partially supported by grants from Chinese Academy of Sciences and 863 Program of Chinese Ministry of T \& S. We thank Professor M. Goodfellow and Professor Z. H. Liu for valuable suggestions. 


\section{References}

Bell, K. S., Philp, J. C., Aw, D. W. J. \& Christofi, N. (1998). The genus Rhodococcus. J Appl Microbiol 85, 195-210.

Bendinger, B., Rainey, F. A., Kroppenstedt, R. M., Moormann, M. \& Klatte, S. (1995). Gordonia hydrophobica sp. nov., isolated from biofilters for waste gas treatment. Int J Syst Bacteriol 45, 544-548.

Brandão, P. F. B., Maldonado, L. A., Ward, A. C., Bull, A. T. \& Goodfellow, M. (2001). Gordonia namibiensis sp. nov., a novel nitrile metabolising actinomycete recovered from an African sand. Syst Appl Microbiol 24, 510-515.

Chun, J., Blackall, L. L., Kang, S.-O., Hah, Y. C. \& Goodfellow, M. (1997). A proposal to reclassify Nocardia pinensis Blackall et al. as Skemania piniformis gen. nov., comb. nov. Int J Syst Bacteriol 47, 127-131.

Collins, M. D. (1985). Isoprenoid quinone analyses in bacteria classification and identification. In Chemical Methods in Bacterial Systematics, pp. 267-284. Edited by M. Goodfellow \& D. E. Minnikin. New York: Academic Press.

Gilbert, S. C., Morton, J., Buchanan. S., Oldfield, C. \& McRoberts, A. (1998). Isolation of a unique benzothiophene-desulphurizing bacterium, Gordona sp. strain 213E (NCIMB 40816), and characterization of the desulphurization pathway. Microbiology 144, 2545-2553.

Kämpfer, P., Dott, W. \& Kroppenstedt, R. M. (1990). Numerical classification and numerical identification of some nocardioform bacteria. J Gen Appl Microbiol 36, 309-331.

Kim, S. B., Brown, R., Oldfield, C., Gilbert, S. C. \& Goodfellow, M. (1999). Gordonia desulfuricans sp. nov., a benzothiophenedesulphurizing actinomycete. Int J Syst Bacteriol 49, 1845-1851.

Komagata, K. \& Suzuki, K. (1987). Lipids and cell-wall analysis in bacterial systematics. Methods Microbiol 19, 161-203.

Kummer, C., Schumann, P. \& Stackebrandt, E. (1999). Gordonia alkanivorans sp. nov., isolated from tar-contaminated soil. Int J Syst Bacteriol 49, 1513-1522.

Lechevalier, M. P. \& Lechevalier, H. (1970). Chemical composition as a criterion in the classification of aerobic actinomycetes. Int J Syst Bacteriol 20, 435-443.

Lechevalier, M. P. \& Lechevalier, H. A. (1974). Nocardia amarae sp. nov., an actinomycete common in foaming activated sludge. Int J Syst Bacteriol 24, 278-288.

Lee, S. T., Lee, S. B. \& Park, Y. H. (1991). Characterization of a pyridine-degrading branched Gram-positive bacterium isolated from the anoxic zone of an oil shale column. Appl Microbiol Biotechnol 35, 824-829.

Linos, A., Steinbüchel, A., Spröer, C. \& Kroppenstedt, R. M. (1999). Gordonia polyisoprenivorans sp. nov., a rubber-degrading actinomycete isolated form an automobile tyre. Int J Syst Bacteriol 49, 1785-1791.

Linos, A., Berekaa, M. M., Steinbüchel, A., Kim, K. K., Spröer, C. \& Kroppenstedt, R. M. (2002). Gordonia westfalica sp. nov., a novel rubber-degrading actinomycete. Int J Syst Evol Microbiol 52, $1133-1139$

Marmur, J. (1961). A procedure for the isolation of deoxyribonucleic acid from microorganisms. J Mol Biol 3, 208-218.

Marmur, J. \& Doty, P. (1962). Determination of the base composition of deoxyribonucleic acid from its thermal denaturation temperature. J Mol Biol 4, 109-118.

Nazina, T. N., Xue, Y., Wang, X., Grigoriyan, A. A., Ivoilov, V. S., Belyaev, S. S. \& Ivanov, M. V. (2000). Diversity and activity of microorganisms in the Daqing oil field of China and their potential for biotechnological applications. Resour Environ Biotechnol 3, 161-172.

Rhee, S. K., Chang, J. H., Chang, Y. K. \& Chang, H. N. (1998). Desulfurization of dibenzothiophene and diesel oils by a newly isolated Gordona strain, CYKS1. Appl Environ Microbiol 64, 2327-2332.

Saddler, G. S., Tavecchia, P., Lociuro, S., Zanol, M., Colombo, L. \& Selva, E. (1991). Analysis of madurose and other actinomycete whole cell sugars by gas chromatography. J Microbiol Methods 14, 185-191.

Smibert, R. M. \& Krieg, N. R. (1981). General characterization. In Manual of Methods for General Bacteriology, pp. 409-443. Edited by P. Gerhardt, R. G. E. Murray, R. N. Costilow, E. W. Nester, W. A. Wood, N. R. Krieg \& G. B. Phillips. Washington, DC: American Society for Microbiology.

Stackebrandt, E. \& Goebel, B. M. (1994). Taxonomic note: a place for DNA-DNA reassociation and 16S rRNA sequence analysis in the present species definition in bacteriology. Int J Syst Bacteriol 44, 846-849.

Stackebrandt, E., Smida, J. \& Collins, M. D. (1988). Evidence of phylogenetic heterogeneity within the genus Rhodococcus: revival of the genus Gordona (Tsukamura). J Gen Appl Microbiol 34, 341-348.

Stackebrandt, E., Rainey, F. A. \& Ward-Rainey, N. L. (1997). Proposal for a new hierarchic classification system, Actinobacteria classis nov. Int J Syst Bacteriol 47, 479-491.

Takeuchi, M. \& Hatano, K. (1998). Gordonia rhizosphera sp. nov. isolated from the mangrove rhizosphere. Int $J$ Syst Bacteriol 48, 907-912.

Tsukamura, M. (1971). Proposal of a new genus, Gordona, for slightly acid-fast organisms occurring in sputa of patients with pulmonary disease and in soil. J Gen Microbiol 68, 15-26.

Yoon, J.-H., Lee, J. J., Kang, S.-S., Takeuchi, M., Shin, Y. K., Lee, S. T., Kang, K. H. \& Park, Y.-H. (2000). Gordonia nitida sp. nov., a bacterium that degrades 3-ethylpyridine and 3-methylpyridine. Int J Syst Evol Microbiol 50, 1203-1210.

Zhang, W., Xue, Y., Ma, Y., Zhou, P., Ventosa, A. \& Grant, W. D. (2002). Salinicoccus alkaliphilus sp. nov., a novel alkaliphile and moderate halophile from Baer Soda Lake in Inner Mongolia Autonomous Region, China. Int J Syst Evol Microbiol 52, 789-793. 